\section{Breaking Good Learning from the Practice of Charles and Ray Eames}

Daniel S. Friedman

University of Hawaii at Manoa
Everything is broken.

$$
\text { -Bob Dylan (1989)1 }
$$

C.E.:

The idea of design as a development of a series of progressive sketches is romantic and not very true.

It is more an optimizing process that is apt to start from a series of hunches which are either developed or discarded by purely intellectual means long before any sketch or model is made.

When these hunches finally begin to combine in such a way that they seem to satisfy more aspects of the problem than anyone has a right to expect, then this is the beginning of a concept.

When the concept is formed it represents about 5 percent of the design effort-the remaining 95 percent of the effort being used to keep the concept from falling apart.

- Ray Eames, handwritten notes $(1964)^{2}$

Charles and Ray Eames have strongly influenced my architectural development, in two ways.

First of all, in my approach to life and my profession: their house in the Pacific Palisades is what can be called the flag of "the liberation movement"-liberation from the slavery of rhetoric and style in architecture. A soft, almost innocent way to violate the sacred canons.

Then comes the poetic aspect: the lightness of the spaces, conceived either in a physical or metaphysical way; their immateriality; the transparency of their multiple planes; their contact with nature; the textures of the materials from which they were created; their frugality and complexity-all this made with the nonchalance of great people, of those who know how to humbly accept the desanctifying idea of "temporariness" in architecture.

This is what I have learned from them, and I try to make good use of it.

$$
\text { -Renzo Piano (1996) }
$$

While serving as Harvard University's 1970-71 Charles Eliot Norton Professor of Poetry, Charles Eames delivered a series of six lectures under the general topic, "Problems Relating to Visual Communication and the Visual Environment." ${ }^{\prime \prime}$ Ray, his wife and partner-in tribute to Charles, who died in 1978-edited and adapted excepts and images from one of these lectures, creating a film she entitled "Goods." "Goods" is the last of 125 films Charles and Ray produced in the office they ran for 45 years out of a repurposed garage at 901 Washington Boulevard, in Venice, Los Angeles, therefore it is the last cinematic project in the Eames's iconic collaboration. ${ }^{5}$ 
Ray's film version of Charles's lecture reconstitutes the images Charles presented using their famous three-screen format; the film runs six minutes and twenty-five seconds. As edited, the film contains just 875 words, none of them the word "design."' Given the unusual context of its production, "Goods" is less a lecture than a summa of Charles and Ray Eames's philosophy of practice. Within this practice, the Eameses use film almost as a process, to both structure and document their "research." This research addresses recurring themes: materials; systems; form (both natural and manufactured); popular culture and history; information and media; the aesthetics of science, technology, engineering, and math; the inseparability of experience and composition; design as a way of both knowing and making known. Their methodology is immersive, open-ended, and contingent. Like so many other topics in their filmography, "Goods" demonstrates the poetic fruit of "tacit" research, building on Michael Polanyi's characterization of "tacit knowledge" as "knowing more than we can tell" at all levels of a problem world-functional, phenomenal, semantic, and ontological.7 Through this and related programs of research, both empirical and analogical, the Eames produced some of the twentieth century's most celebrated designs, including a molded plywood lounge chair, "LCM," heralded by Time Magazine as the greatest design of the twentieth century. ${ }^{8}$

"Goods" knows more than it can tell. Although Charles Eames calls the topic of this lecture "the new covetables," his talk consists of reflections built around seven old and commonplace products. Charles Eames opens the lecture with a story about a thief who breaks into Ray's car. The thief leaves Ray's possessions strewn all over the parking lot next to their office. Eames describes this latenight crime scene with an air of disbelief, since the thief ignores almost everything of any value, in particular a bolt of cloth so noteworthy that Eames can't help but trumpet it virtues: "when you take hold of it," he says, "why, you can feel the animal wax and oil in it-a great bolt of cloth." Eames cannot believe "the [thief] hadn't thought enough of it to steal it ... A bolt of cloth comes under the heading of 'goods,"' Eames explains. "People lay great store in [goods]," he saysgoods give people a feeling of "tremendous security." To illustrate this claim, he conjures up the Manly party crossing Death Valley in 1849 on their way to California. In fear of indigenous belligerents, he explains, the settlers wrap themselves in every piece of fabric they own, to protect their precious inventory. Here Eames deftly segues into a series of comparable goods - "a reel of line," "a ball of twine," "a keg of nails," "reams of paper," "boxes of chalk," "a cord of wood." Much of this typology suggests old (even sometimes obsolete) modes of distribution.

Eames seems sincerely moved by the intermediate spatial orders and circulation of bulk goods, and especially by the material and formal correspondence of carton and contents, also the tactile and motor signatures of each product at the point of sale and consumption. His elliptical vignettes resemble the poetry of Francis Ponge, in The Voice of Things- "The Orange," for instance, where Ponge gingerly examines each sensorial layer of Citrus aurantium, peel to pip.

At the end of too brief a study [Ponge writes], conducted as roundly as possible, one has to get down to the pip. This seed, shaped like a miniature lemon, is the color.of the lemon tree's whitewood outside, and inside is the green of a pea or tender sprout. It is within this seed that one finds-after the sensational explosion of the Chinese lantern of flavors, colors and which is the fruited ball itself-the relative hardness and greenness (not entirely tasteless, by the way) of the wood, the branch, the leaf; in short, the puny albeit prime purpose of the fruit.?

Like Ponge, Eames encircles a phenomenology of the everyday-wool presupposes coat; rope, knot; twine, wrapping; nail, shingle; chalk, blackboard; bond, typewriter; wood, fireplace. Note how Eames extols the pleasure of tearing open the wrapper of a fresh ream of paper: "What you do with [it] can never quite come up to what [it] offers in itself."

Eames ends his tribute to goods with a common cord of firewood, "one of the most covetable things you can imagine" (the only other place in the film he uses this word after the first sentence, hence a clue to his true topic). Wood is a primordial source of both energy and social continuity. In the final sentence of the talk, Eames addresses "that moment when somebody [would first] eat into the cord of wood, the first one to take the piece out, and it would start to tumble, and before you knew it, the cord of wood was gone." In contrast to Eames's description of twine as a material that feels like "it's going on forever," or a bushel of apples "you think is going to last forever," or a keg of nails ("how can you ever run through it?"), the last word of the film is "gone," unexpectedly final, a word that lingers in the mind like a fading bell. Here Eames plumbs a deeper question about the structure of reality, not dissimilar to Buddhist philosophy, which regards all form as "the sport of emptiness." ${ }^{10}$ The indivisibility of form and emptiness is the most widely-referenced principle of Shakyamuni Buddha's famous Heart Sutra, which ends with the mantra "... gone, gone, gone beyond... "11 Eames's final comment on the fate of all goods recalls the Buddha's own last words, circa 400 BCE: "All created things have the nature of destruction." ${ }^{\prime 2}$

Harvard established the Charles Eliot Norton professorship in 1925 to explore "poetry in the broadest sense"-besides Eames, recipients include T.S. Eliot, Robert Frost, Siegfried Giedion, Igor Stravinsky, Erwin Panofsky, Aaron Copeland, E.E. Cummings, Herbert Read, Ben Shahn, Pier Luigi Nervi, Georg Luis Borges, Lionel Trilling, Octavio Paz, Leonard Bernstein, Frank Stella, Italo Calvino (generating his iconic Six Memos for the Next Millennium), Harold Bloom, John Cage, John Ashbery, Umberto Eco, Nadine Gordimer, Leo Steinberg, Orhan Pamuk, Herbie Hancock, Toni Morrison, and Wim Wenders, among others. ${ }^{13}$ The contribution of the topic of "Goods" to Eames's larger theme-" Problems Relating to Visual Communication and the Visual Environment"-revolves around his juxtaposition of two interconnected but discrete nouns, which he introduces in the plural: "Goods," of course, which is the title Ray later gives to the film version of his lecture; and the noun "covetable[s]" - "the new covetables," in this case-a neologism essential to Eames's theme. "Goods," "covetables," and every other word he uses in this presentation are 
the product of rigorous poetic distillation, much the way prose functions in the philosophical poetry of Francis Ponge.

Eames constructs the noun "covetables" from the adjective form of the verb "covet," which shares its root with the name of Cupid, god of love (from the Latin cupido, desire). To covet means "to desire eagerly, to wish for, long for," beyond the practical proportions of necessity (such as need or want), more within the orbit of craving or lust. ${ }^{14}$ Where covetousness departs from desirability is in the nature of its object: things we covet typically lie just beyond reach; not infrequently, they are things possessed by others. "Covetable" describes the condition of being ardently desirable, conjoining desire with excess. The phrase "new covetables" therefore suggests a class of objects that have somehow earned heightened status in the world of material consumption. After the first sentence of the film - "This one is going to have something to do with what I think of as 'The New Covetables'..."that's the last we hear of them. Strictly speaking, Eames offers nothing new. Instead, he evokes things that are expressly old: woven wool, 1500 BCE; blackboard chalk, 11th century; paper, the first century; nails, 3400 BCE; rope, 3500 BCE; and firewood, warming and lighting the world of homo sapiens for a thousand millennia.

So instead of "New Covetables," instead of novelty and the aesthetics of desire, Eames explores utility and the aesthetics of fitness for use, the common look of common things, "things that are produced for sale; commodities and manufactured items to be bought and sold; merchandise, wares; ... economic assets [that] have a tangible, physical form." ${ }^{15}$ He situates these seven ordinary products in close proximity to the other meaning of "good"- "beneficial"- "the most general and most frequently used adjective of commendation in English," according to the Oxford English Dictionary, "and one of the most common non-possessive adjectives in all periods from Old English to the present day. Almost all uses convey the sense of being of a high (or at least satisfactory) quality, useful for some purpose (specified, implied, or generally understood), and worthy of approval"- efficacious, sound, fit, suitable, "sufficient in every respect ... ; thorough; complete, utter."16

Charles Eames's folksy tone in "Goods" belies a more serious purpose. From beginning to end, "Goods" explores acts of "breaking into," starting with Ray's car and the theft of a broken alarm clock (boxed, wrapped, and addressed to a nephew for "further dismantling"), with which Eames breaks time's grip on the fixity of "old" and "new"; a hank of rope (so perfect "you don't want to break into it"); a ball of twine ("there is something so special about [it] before the moment that it's opened up and gotten into"); a keg of nails (synonym for anything "broken into [because] in the house somebody would always refer to it as 'breaking into the keg of nails'"); a ream of paper ("there's something about that broken package, where the corner is torn, and it invites you to come in it"); and a cord of wood (which once broken into starts to tumble, "and before you [know] it, the cord of wood [is] gone"). "Goods" doesn't lament lost authenticity and craft, rather it illuminates qualities of found economy and concinnity in the character of goods whose virtues transcend the feverish commercialization of the modern. The Eameses stated goal in "Goods" and the other five Norton lectures "was that 'the rewarding experiences and aesthetic pleasures of our lives should not be dependent solely upon the classic fine arts, but should be, rather, a natural product of the business of life itself." 17

Tacit knowledge drives the Eameses' exploration of tacit beauty, which since Vitruvius in 27 BCE emerges as a theory of the unity of relation between part and whole. Yet the Eames's criteria for beauty is contingent, mutable, open, and incomplete, a radical departure from its classical antecedent. The most authoritative definition of classical beauty issues from Leon Battista Alberti, in his fifteenth century treatise, On the Art of Building in Ten Books: "Beauty is that reasoned harmony of all the parts within a body, so that nothing may be added, taken away, or altered, but for the worse." ${ }^{18}$ The classical understanding of beauty is far too static a gestalt for the Eames and their action practice. In "Goods," the Eameses reveal beauty not in objects and their individual forms and proportions, nor even in their beautifully composed photographs of these objects, lovingly arranged into the Eames's famous multi-screen slide shows and their revelatory narratives. Rather, they re-present these objects in contexts that suggest an aesthetics of utility commensurate with traditional Japanese packaging, an art form in itself, seamlessly integrating the material and formal properties of the object being wrapped with the means and methods of wrapping it.

Through this attention to packaging, which addresses problems related to the economy of goods (their life and circulation in time, from raw material to refuse)-the spatial geometry and engineering of large quantities, movement from point of manufacture to point of sale, circulation, display, wholesale and retail storage and dispensation-the Eameses engage a ratio of order to flux: systems, processes, thresholds, fields, boundaries, hybridity, economy, and the ecologies of production and consumption. From their earliest days in practice onward, the Eames seem drawn "from objects to events, and from substance to process." ${ }^{19}$ In this film and across the full spectrum of their practice, the Eameses continually dismantle the commercial logics of "modern design," especially those aspects of it that reside less in form or purpose than the luster of novelty and desire, as though mindful that the psychological reality of longing (what Lacan calls "object petit a") is in its essence nothing either design, possession, or consumption can satiate, much less extinguish. ${ }^{20}$

The practice of Charles and Ray Eames blossomed in the early 1940s, when they were teachers at Cranbrook, following their now-famous, problem-driven research and experimentation with molded plywood. Like Le Corbusier, Louis Kahn, Alvar Aalto, and their close friend and collaborator Eero Saarinen, the Eameses sought to reconcile standards versus standardization. ${ }^{21}$ Experimentation with molded plywood is the wellspring of the Eames's early research, their career-launching hunch, which led to the Evans "plyformed" emergency transport splint, designed and manufactured for the U.S. Navy in 1942. ${ }^{22}$ The splint, much coveted by 
collectors, evolved from their earliest investigations, inspired by their design and construction from scratch of a machine called "Kazam!"something that appears as though by magic. Kazam perfected the plywood molding technology, blossomed into the splint, facilitated the production of Eames's first mature series of molded plywood furniture, and set the stage for their long, ongoing affiliation with Herman Miller, which as of this writing features over one hundred products designed by Charles and Ray Eames. ${ }^{23}$

From the beginning, the Eameses make no distinction between practice and ethics. Their methodology privileges topics and problems over clients, budgets, and briefs. ${ }^{24}$ Ethics therefore comes to life in their optimization of form within problem-worlds delimited not by profit, connoisseurship, or brand so much as the skillfully contextual integration of anecdote, data, observation, and analogy. For the Eameses, architecture was neither self-referential nor autonomous, but rather fully situated in the contingencies and fluidity of modern experience, "the ongoing spectacle of everyday life, understood as an exercise in restrictions rather than self-expression." 25 This orientation to practice inhabits all their work, much of it documented in the 125 short films they produced, still celebrated in their furniture designs, most of which has remained in continuous production, unrivaled in reputation or esteem, although nowadays the Eames name populates a class of products well beyond the reach of average households. ${ }^{26}$

As their practice evolved, the Eameses increasingly employed film to research and document the flows and velocities of contemporary experience, with particular interest in local and global popular culture, literacy, science, mathematics, physics, technology, and government-titles included "Bread" (1953); "Two Baroque Churches in Germany" (1955); "Lounge Chair" (1956); "Information Machine: Creative Man and the Data Processor" (1957)' "Tops" (1957); "The Expanding Airport" (1958); "Glimpses of the USA" (1959); "IBM Mathematics Peep Shows," on Eratosthenes, functions, symmetry, and topology (1961); "The House of Science" (1962), "Think," addressing large-scale problem-solving (1964); "A Small Hydromedusan: Polyorchris Haplus," the movement of a time jellyfish (1970); "Computer Landscapes" (1971); "Clown Face" (1971); "Alpha," a film about an important concept in algebra that can be viewed backwards and forwards (1972); "SX-70," on the Polaroid Land camera (1972); "Copernicus" (1973); "Kepler's Laws" (1974); "Newton's Methods of Fluxions" (1974); "The World of Franklin and Jefferson" (1976); Powers of Ten" (1977); "Cezanne: The Late Work" (1978); "Degas in the Metropolitan" (1978); and "Goods" (1981). ${ }^{27}$ They use film to document a broad, transdisciplinary cross-section through mid-century modern experience, fully opening the world of design thinking and design labor to view. From their first hunch forward, almost all of the Eames's extraordinary output subsumes the commercial sovereignty of clients, programs, sites, scope, budgets, and briefs within their independent research enterprise, in testament to an ethical transposition that "understood all their work as a gift." ${ }^{28}$ Charles Eames elaborates: "The motivation behind most of the things we've done was either that we wanted them ourselves, or we wanted to give them to someone else. And the way to make that practical is to have the gifts manufactured." ${ }^{29}$ As Lewis Hyde notes, "gift property serves an upward force":

If commodity moves to turn a profit [Hyde asks], where does the gift move? The gift moves toward the empty place. As it turns in its circle it turns toward him who has been empty-handed the longest, and if someone appears elsewhere whose need is greater it leaves its old channel and moves toward him. Our generosity may leave us empty, but our emptiness then pulls gently at the whole until the thing in motion returns to replenish us. ${ }^{30}$

For Charles and Ray Eames, "everything was thought of as a gift. Design was gift giving .... [T] he Eames said that their 'objective is the simple thing of getting the most of the best to the greatest number of people for the least."'31

The Eames's practice helps us distinguish between the design of the good and the good of design, which both our professional curriculum and our professional culture frequently confuse or conflate. For purposes of argument, allow me to hazard a provisional distinction between these two phrases. "The design of the good" is how the market economy answers the question of ethics, in its effort to address capital inequities, by representing "the good" as the equivalent of a brand, which ensnares it in ceaseless commodification, where abundance manifests the locus of emptiness. "The good of design," on the other hand, is how the gift economy questions the answer of capital, in its effort to address ethical inequities, by representing "the good" as the equivalent of an offering, which liberates it in ceaseless circulation, where emptiness manifests the locus of abundance. ${ }^{32}$

\section{NOTES}

1. Broken lines, broken strings

Broken threads, broken springs

Broken idols, broken heads

People sleeping in broken beds

Ain't no use jiving

Ain't no use joking

Everything is broken

Broken bottles, broken plates

Broken switches, broken gates

Broken dishes, broken parts

Streets are filled with broken hearts

Broken words never meant to be spoken

Everything is broken

Seem like every time you stop and turn around

Something else just hit the ground

Broken cutters, broken saws

Broken buckles, broken laws

Broken bodies, broken bones

Broken voices on broken phones 
Take a deep breath, feel like you're chokin'

Everything is broken

Every time you leave and go off someplace

Things fall to pieces in my face

Broken hands on broken ploughs

Broken treaties, broken vows

Broken pipes, broken tools

People bending broken rules

Hound dog howling, bullfrog croaking

Everything is broken

Bob Dylan, "Everything is Broken," on Oh Mercy (1989). Official lyrics available at http://www.bobdylan.com/songs/ everything-broken/ [accessed June 21, 2019].

2. Ray Eames, handwritten notes, dated July 1964, "Undated or unidentified notes and transcript" folder, Part II: Speeches and Writing series, Charles and Ray Eames Papers, Manuscript Division, Library of Congress, Washington, D.C., from Ray Eames, "Handwritten Notes on Design," in Charles and Ray Eames, An Eames Anthology: Articles, Film Scripts, Interviews, Letters, Notes, Speeches, ed. Daniel Ostroff (New York: Yale University Press, 2015), 247.

3. Renzo Piano, "Appreciations," in Donald Albrecht, ed., The Work of Charles and Ray Eames: A Legacy of Invention (New York: Harry N. Abrams, 1997), 181.

4. Ray Eames, "Goods," ibid., 307-08; see also Wikipedia, s.v. "Charles Eliot Norton Lectures," https://en.wikipedia.org/wiki/ Charles_Eliot_Norton_Lectures [accessed June 21, 2019].

5. See "Filmography," in Albrecht, ed., The Work of Charles and Ray Eames: A Legacy of Invention, 188-193.

6. This word count and subsequent quotations issue from the author's transcription of the film, which seeks to capture the unique flavor of Charles Eames's locution. For an authoritative transcription, see Ray Eames, "Goods," in Charles and Ray Eames, An Eames Anthology: Articles, Film Scripts, Interviews, Letters, Notes, Speeches, 307-08.

7. Michael Polanyi, The Tacit Dimension (Chicago: University of Chicago Press, 2009), 3-25. My thanks to Billie Faircloth for introducing me to Polanyi and his work on tacit knowledge.

8. "Best Design: The Eames molded plywood chair, designed by Charles Eames (1946). Eames took technology created to meet a wartime need (for splints) and used it to make something elegant, light and comfortable. Much copied but never bettered." In "The Best of the Century," TIME Magazine 154
(December 31. 1999): 73.

9. Ponge, The Voice of Things, trans. Beth Archer (New York: McGraw Hill, 1974), 36-37.

10. The Fourteenth Dalai Lama (H.H.Tenzin Gyatso), Kindness, Clarity, and Insight, trans. and ed. Jeffrey Hopkins (Ithaca: Snow Lion, 1984), 165

11. "Gate, Gate, Paragate, Parasamgate, Bodhi Svaha." Gate means "gone." Translations vary. See https://www2.kenyon. edu/Depts/Religion/Fac/Adler/Reln260/Heartmantra.htm [accessed June 21, 2019].

12. Robert A.F. Thurman, Essential Tibetan Buddhism (New York: HarperCollins, 1995), 93.

13. For the full list of Norton lecturers, see Wikipedia, s.v. "Charles Eliot Norton Lectures," https://en.wikipedia.org/wiki/Charles_ Eliot_Norton_Lectures [accessed June 21, 2019].

14. See Oxford English Dictionary, s.v. "covetable" and "covet," https://www-oed-com.eres.library.manoa.hawaii.edu/ view/Entry/43389?redirectedFrom=covetable\#eid [accessed June 21, 2019]

15. Ibid., s.v. "goods," https://www-oed-com.eres.library.manoa. hawaii.edu/view/Entry/79925?rskey=7ltVKj\&result=1\#eid [accessed June 21, 2019]

16. Ibid.

17. Charles Eames, interview with Digby Diehl, "Charles Eames Q\&A," Los Angeles Times WEST Magazine (Oct. 8, 1972): 14, reprinted in Digby Diehl, Supertalk (New York: Doubleday, 1974), quoted in Beatriz Colomina, "Reflections on the Eames House," in Albrecht, ed., The Work of Charles and Ray Eames: A Legacy of Invention, 128.

18. Joseph Rykwert and Robert Tavernor, "Glossary," in Leon Battista Alberti, On the Art of Building in Ten Books, ed. and trans. J. Rykwert and R.Tavernor (Cambridge: MIT Press, 1988), 421-22.

19. Lonchenpa, Kindly Bent to Ease Us Part Three: Wonderment, trans. and ed. Herbert V. Guenther (Berkeley: Dharma Publishing, 1976), 33.

20. See Malcolm Bowie, Lacan (Cambridge: Harvard University Press, 1991), 165-178; also Bruce Fink. The Lacanian Subject: Between Language and Jouissance (Princeton, NJ: Princeton University Press, 1995), 83-97. 
21. See Charles Eames, "Design Today," in Charles and Ray Eames, An Eames Anthology: Articles, Film Scripts, Interviews, Letters, Notes, Speeches, 5; also Charles Eames, "Organic Design," ibid., 6; also Louis I. Kahn,"'Standards' Versus Essential Space: Comments on Unit Plans for War Housing," in Alessandra Latour, ed., Louis I. Kahn: Writings, Lectures, Interviews (new York: Rizzoli, 1991), 14-17.

22. See Wendell G. Scott and Charles Eames, "A New Emergency Transport Splint of Plyformed Wood," United State Medical Bulletin 41., no. 5 (September 1943): 1424-28, republished in Charles and Ray Eames, An Eames Anthology: Articles, Film Scripts, Interviews, Letters, Notes, Speeches, 14-15.

23. For an excellent summary of the historical and institutional context of the Eames's research into molded plywood manufacturing technologies, which culminated in the construction of the game-changing "Kazam Machine" in a spare room of their Los Angeles apartment-from WWII splint to see Pat Kirkham, Charles and Ray Eames: Designers of the Twentieth Century (Cambridge, MA: The MIT Press, 1995), 201-231. A 108-second animation on the history of the Herman Miller Company devotes 15 seconds to the Eames-see "Our Story," https://store.hermanmiller.com/about-us.html?lang=en_US [accessed June 21, 2019]. The Heman Miller website lists 106 individual items in the Eames collection, from molded plywood and polypropylene elephants and bird sculptures to storages and seating systems, featuring couches, chairs, and tables of all sizes, materials, colors, and finishes. For the full inventory, see https://store.hermanmiller.com/search?q=Eames\&lang=en_US [accessed June 21, 2019].

24. Kirkham, 258-60. "After the early 1950s the Eames were concerned less with low-cost furniture than with solving particular problems: making a comfortable lounge chair, or a chair that could be used indoors and out, or a storage unit for students' rooms. Their design work was not market-driven; they did not self-consciously or cynically set out to design for the lucrative contract market. They generally deplored the high production costs of their designs, but their priority was always the thorough resolution of each brief, whatever it might be."

25. Beatriz Colomina, "Reflections on the Eames House," in Albrecht, ed., The Work of Charles and Ray Eames: A Legacy of Invention, 128.

26. Herman Miller and Design Within Reach sell the Eames Lounge Chair and Ottoman beginning at \$6195 retail, excluding tax and shipping. See https://www.dwr.com/living-lounge-chairs/ eames-lounge-chair-and-ottoman/5667.html?lang=en_US.

27. Colomina, in The Work of Charles and Ray Eames: A Legacy of Invention,138.
28. See "Filmography," in Albrecht, ed., The Work of Charles and Ray Eames: A Legacy of Invention, 188-193.

29. Digby Diehl, "Charles Eames Q\&A," Los Angeles Times WEST Magazine (Oct. 8, 1972): 14, quoted in Colomina, in The Work of Charles and Ray Eames: A Legacy of Invention, 138-39.

30. Lewis Hyde, The Gift: Imagination and the Erotic Life of Property (New York: Vintage Books, 1979), 25; and 23.

31. Colomina, in The Work of Charles and Ray Eames: A Legacy of Invention, 138; and Charles Eames, quoted in "A Designer's Home of His Own," LIFE (September 11, 1950): 152, quoted in Colomina, 146.

32. On emptiness and the gift, see Hyde, The Gift, 23-24. 